\title{
Financial Governance and Sustainable Development in Nigeria: A Critical Review
}

\author{
Stephen Ocheni, Ph.D. \\ Ministry of Foreign Affairs, Abuja \\ Email: stephenocheni@yahoo.com \\ Moses Atakpa, Ph.D. \\ Head of Service, Kogi State, Nigeria \\ Basil C. Nwankwo, Ph.D. \\ Professor and Dean, Faculty of Management Sciences, Kogi State University, Anyigba, \\ Nigeria \\ Email: basil.nwankwoy2k@yahoo.com
}

Accepted: August 14, 2012 Published: September 05, 2012

Doi:10.5296/ijld.v2i5.2344ＵRL: http://dx.doi.org/10.5296/ijld.v2i5.2344

\begin{abstract}
The work is a review of the Federal Government application of fiscal and monetary policies to create the necessary healthy environment for sustainable growth and development of the Nigerian state. The review indicates that although the government of Nigeria has designed in theory good fiscal and monetary policies to facilitate sustainable growth and development of all the sectors of the economy, the practical implementation of such policies to attain the desired results has remained an illusion. The problem responsible for the great expectations not matching with the realities on ground is because of lack of budget discipline. The Nigerian government in practical terms most often than not hardly follows the implementation of her annual budget as approved by the National Assembly. Consequently, a lot of extra budgetary activities which amount to both financial and budget indiscipline are experienced in the management of the annual budgets over the years. It is therefore recommended that the Federal Government of Nigeria should maintain strict budget discipline to guarantee good financial governance which is a necessary condition for sustainable development.
\end{abstract}

Keywords: Financial Governance, Sustainable Development, Money Market, Policy

\section{Introduction}

When Crowther, in Swammy (1985) was talking of money, as the bedrock of discovery in economics and financial management, in the whole public and commercial sectors and for the social existence of man, he was in fact, demonstrating the universal importance of finance. Peter Abraham in Mine Boy was describing the power of money and informs us that with money one can achieve anything (Abraham, 1979). In the early days of development, finance 
was only seen as a means of exchange for mere living and sustainability. Finance was with gradual development and in the $15^{\text {th }}$ century, it was used for the monarch and the kings (for the palace maintenance) with a view to maintaining law and order and for good governance. Little was seen of finance as the main expansionary phenomenon for diverse and decisive development, which modern development has proved for expansionary and real development. It shows that finance does not have to concentrate on the oligarchic maintenance of the palace only but there is the need for general development. The service to the people demands public services delivery. This service centre on policies aimed at general development (i.e. both urban and rural development). This is so because there is the need for broad financial resources to tackle the numerous societal needs and development including social, economic, political and rural development. In addition to the public finance and fiscal policy, the need for the real value of the purchasing power should be considered, so also to show a realistic development. In other words, the monetary policy should be addressed. This is so due to the fact that the monetary policy aims at determining the real worth of money in circulation and the cost of capital and the interest rate involved. In substantiating the effect of finance on sustainable development, we should look at the policies involved in enhancing development, especially such policies that are sustainable and laudable. Development is the improvement of human's material needs, social and economic condition as well as man's social cultural, political, economic, institutional and technological life as cultural advancement (Nzenwa, 2000). It is a positive change. Oduran sees development as form of change from a prior condition to a better one (Oduran in Omoruvi, 2001). Development therefore is a gradual growth or advancement through progressive change in all variables of man's existence. It could be the discovery of such variable as economic advancement, social improvement, exhibition of political ingenuity and cultural growth. Sustainable development is the managed and controlled development in such a way that recognizes the dynamic nature of social, political, cultural and technological factors in the society. The process of development involves such identifiable features of growth that address the social, economic, political and environmental conditions of the society. The process of development and the ability to retain and control such change, is sustainable development. For an enduring development in a society, there should be effective financial policies in such society. In other words sustainable development is synonymous with public finance and its management. The management of public finance involves the fiscal and monetary management. Public finance is the study of public authorities (government) in generating revenue, allocating revenue (i.e. spending) and debt management towards ensuring efficiency of the state and the well being of the people (Salawu, 2005). According to Ato in Salawu (2005), public finance is the study of fund raised by government to meet the cost of government. Public finance is also the study of incomes and expenditure of the central, state and local governments for the collective satisfaction of wants on the principles which govern income and expenditure.

However, public finance, being about money and its importance, especially in government, should reflect on the source of fund and its cost. In other words the worth of fund is very necessary in determining the state of an economy. And for effective, stable economy, the enactment and implementation of policies that would regulate the cost of fund is very necessary. In other words, the income and expenditure policy of government should include the cost of fund of such income hence the need for monetary policy which determines the money in circulation and the interest rate (i.e. cost of capital) and of course the management of both (i.e. public debt). 
Fiscal policy: Fiscal policy refers to the tax structure and the determination of the amount of tax revenue and the amount and direction of government expenditure for the purpose of attaining specific objectives such as balance of payment equilibrium or the avoidance of inflation (Uzoaga, 1984:162). For the sustainability of any economy, the fiscal policy of the government should be vigorously followed by the agents of the government. An economically sound fiscal policy of the government is indispensable for sustaining such country. The instrument of fiscal policy are varied and they include such items as taxes that are levied and their features such as exemptions allowable, deductions, schedules of rates, modes and procedures of government expenditures etc. The execution of a tax structures is aimed at achieving a given objective and it is undertaken not mainly due to the amount of revenue that could be raised because of the effect that specific kinds of taxes and their different schedules of rates and duties will have upon consumption, saving, domestic investment and foreign investment. Fiscal policy is aimed at moderating the economy in such a way that not only brings the balance of payment to equilibrium but will help in raising the Gross National Product and the Gross Domestic Product to a higher standard. For the government budget to achieve its aim, the fiscal policy of the government would be explicitly expressed. It gives the government the sense of purpose and direction as to what measures to be undertaken during the fiscal period.

Monetary policy: The monetary policy is the management of the expansion and contraction of the volume of money in circulation for a specific purpose, achieving certain declared national objective (Uzoaga, 1984). The monetary and banking policies of the government are aimed at controlling the volume of money in circulation. It is principally aimed at controlling the inflationary trend in the economy of the state. In other words, monetary policy is the policy of the government geared towards checking the inflation in economy and raising the standard of living. The execution of monetary structures is geared towards strengthening the currency of the state comparatively. Every country makes effort to ensure that her currency is qualitative enough to have a bargaining power and is recognized internationally. In finance and economics, the quantity theory of money is the product of money multiplier and the high powered money (Peter, 2005). The money multiplier shows how the change in the quantity of money can affect the money base while the high powered money shows the total amount of currency held in circulation and the bank reserve. The central bank of a country influences the money multiplier in desired direction. In other words, the government influences the quantity of money through the apex bank i.e. the central bank/reserve bank.

The government regulates the quantity of money so as to give the money its effective functionality of unit of account, exhibit the economic worth or financial position of entity, medium of exchange which serves as a means of procuring or exchanging goods and services, store of value for its durability and as a standard of deferred payment for any future demands/desires.

For the government to achieve its objective of good governance, the implementation of fiscal and monetary policies is very necessary. Hence the government will continue to maintain, manipulate and manage the policies, so as to achieve its aim. For its bid to affect a stable economy, the government's manipulation of the fiscal and monetary policies creates public debt.

\section{Public Debt}


Public debt is aggregate instrument owed by the state. It is usually quantified in monetary terms. In other words, it is the amount of money owed by the state (i.e. government). The meeting point of fiscal policy and monetary policy is the management of public debt (Uzoaga, 1984). The management of public debt concerns the determination of the composition of privately held public debt. The fiscal authorities issue the type of securities that determine the structure of public debt. The monetary authorities by their purchase and sale of government securities can affect the size and composition pf public debt held by the private sector. Public debt issue is appropriate in two situations; the first relates to a situation in which government desires to substitute public for private demand upon resources. The second situation is when a stabilization objective is being pursued. For instance when inflation threatens and it is considered a desirable social policy to stop it. Here debt issue provides a means of moderating inflationary pressure since it involves an exchange of debt instruments for money (Uzoaga 1984).

It is worth noting that no country can thrive very well without effective implementation of the fiscal policy, monetary policy and of course, to a large extent debt management. In Nigeria and indeed in all the developing countries, the instability of the country's currencies is attributed greatly to the management of these policies.

\section{Nigerian Financial Development}

Having briefly explained the policy instruments in economic development, we may briefly look at the policy application in Nigerian development. Development is the control and manipulation of environment progressively, with a view to increase production and productivity so as to achieve man's needs in qualitative and high standard form and make him live a better life in the society. According to Nzenwa (2000), it is not only economic growth but economic growth plus positive change in social, cultural and institutional development. Wafure in Peters (2005) sees development as economic growth accompanied by functional change in the structure of the economy plus political, social and economic structure. To him it includes positive change in technology, socio-economic and institutional arrangement that enhances output. For development to be effective there would be effective demand. In other words, it is only finance that enhances effective development. All the developed countries in the world are regarded as such due to their developed economy and their financial policies.

In Nigeria, the policy instruments of fiscal, monetary and debt management are policy impositions. These are direct policies the government uses to achieve economic stability, growth and general development.

The federating state of Nigeria is structured in such a way that gives the centre higher multiplier effect of public spending than private spending for the interest of fast and general development. Hence the federal authority takes precedence in major fiscal decisions. The federal government takes control of more than 70 percent of the internally generated revenues as at 1998 (Federal Ministry of Finance, 1999). Recently the revenue from Customs and Excise duties as projected in the budget proposals, surpassed the amount in the budget implementation. This shows improvement and dexterity on the part of Customs and Immigration officials. The fiscal decisions on such development programs as Defense, Education, Agricultures, International Trade/Foreign Affairs, etc. have put the nation forward. Today, Nigerians are now concerned on the personal development and self help programs. The Millennium Development Goals (MDGs) and International Development Partners (IDP) 
such as United States Agency for International Development (USAID), Department for International Development (DFID), the United Nations' Development Program (UNDP) etc., have been playing a lot of pivotal role for poverty reduction and sustainable development. In fact the MDGs assertion of total eradication of absolute poverty by the year 2015 and Nigeria's Vision 2020 are being vigorously pursued financially and decisively.

The National Poverty Eradication Program (NAPEP), as the federal government agency for poverty reduction, has been playing a lot of interventionist roles towards sustainable development and poverty reduction. The roles include, micro-credit scheme, youth empowerment and capacity enhancement schemes and other programs as may be introduced/directed by Federal Government, World Bank group, Millennium Development Goals and International Development Partners. For instance the United Nations' Education, Social and Cultural Organization (UNESCO) has established Community Skills Development Centres (CSDC), for conflict prevention, management and skills acquisition, while the Department for International Development (DFID) has established many neighborhood centers for community policing and skill acquisitions. Though these are social development programs, but for the fact that huge financial outlay are associated with such ventures and development projects are sustained due to the financial involvement, they are also regarded as financial development (NAPEP, 2005).

On monetary policy, the federal government of Nigeria has put policies that have put the banking sectors afloat; also the general public is having confidence on these financial institutions due to the strong financial base of the financial institution. The interest rate has been $2-3 \%$ and $20-22 \%$ on savings and lending rates respectively. This has put the cost of fund at relatively constant thereby building confidence on the prospective investors. The capitalization base of commercial banks of $\$ 25$ billion (Twenty five billion Naira) and that of micro-finance banks at $\$ 20$ million (Twenty million Naira) only have rather made the commercial banks and the micro-finance banks to be very liquid and financially solid. The external reserve of the country, which is about $\$ 43$ billion (Forty three billion dollars), shows a strong economic base and it helps in the economic growth of the country as it builds confidence among the international investors and the World Bank.

\section{Nigerian Money Market}

Another issue in Nigerian monetary policy is the Nigerian money market. Money market is the market where short term securities are traded. It is a market where money market instruments are bought and sold (Uzoaga, 1984:247). It is very important to both the government and the public including the principal actors such as the banks. The Nigerian government has used money market instruments such as treasury bills, treasury certificates commercial papers, Bankers' unit fund, stabilization securities etc., to regulate the volume of money in circulation and these help in strengthening the value of the local currency i.e. Naira. This also affects the interest rates as mostly, the cost of capital could be affected by these money market instruments (Uzoaga, 1984). The Nigeria money market has really expended overtime. Though there was a rise in the number of banks in the banking sector especially in mid 1980s and early 1990s, but the actual development came between 2004 and date. By huge capitalization of the commercial banks and the relative huge capitalization of the micro-finance institutions, the number of these banks reduced as many went into merger, acquisition and outright liquidation. This brought out real consolidation of the banks that could meet up the capitalization demand. As earlier stated, these banks are well consolidated and are confidence driven. 
On the capital market, the government has improved the economic base of investors through the Security and Stock Exchange Commission. Capital market is that part of financial market that deals on long-term securities and procedures for financial long term investments. It is an investment instrument that encourages both actual long term investments and speculative businesses based on the market process. The Nigeria Stock Exchange which started effectively in 1961 by Lagos Stock Act 1961 with less than $\$ 6$ million, has a capitalization fund of about N7 trillion (seven trillion Naira) only as at May, 2009 (The Nation, 3/6/09:42-43). This shows every remarkable improvement in market economy that faces a nose diving situation due to the global economic meltdown. The Nigeria Stock Exchange has really improved the investment opportunities of Nigerians and the government. Being an organized market it has helped all the companies that wanted to be quoted in the market, to do so and also educate the entire public on the available instrument to invest.

Nigeria insurance institution is another financial institution that needs to be briefly discussed. Insurance organization, being an undeniably organized institution, has been playing some roles towards economic growth of the nation. However, of all the various policies of the government, it is only the insurance institution that its growth is gradual but progressive. The government is not really doing much towards insurance education and investment. The current Pension Act of 2004 gave the National Pension Commission (PENCOM) the responsibility of regulation any supervision of Pension Fund Administration (PFA) and the public service. It not only encourages savings and guarantees public servants safety on retirement but encourages the savings of the private sector insurance. Also the life assurance policy and other insurance policies introduced by the government are aimed at encouraging the people for investment in all sectors of the economy (CBN Economic and Financial Review, 2007).

\section{Conclusion and Recommendations}

Nigeria as a developing nation has made great impact in all sectors of the economy. As rightly put by Crowther in Swammy (1985), that money is the essential invention in all economic, financial management, public and commercial sides of man's social existence, finance has been the bedrock of all the general development of any society. Despite the economic meltdown and the problem of federalism, the Nigeria financial sector and finance development have not only sustained the economic and political growth of the nation, but is improving the economic and political life of the nation.

However, the Nigeria government needs to buckle up on financial discipline especially on budget implementation. The Nigeria budget is mere ritual of ceremonial presentation with total ignominy to the implementation and evaluation. Even at skeletal implementation, it is full of self interest syndrome of me, I and myself, hence this massive abandonment of projects and mere paper presentation of projects, without execution. Also, the high rate of corruption and revelry in Nigeria, calls for total reorientation of our leaders and policy makers. The institution of insurance in Nigeria is yet to develop. There is need for the government and even our insurance technocrats/experts including some serious investors (under the proper guide of the government) to come into the insurance sector and rescue the institution. There is need for public enlightenment campaign on insurance needs and modalities.

\section{References}


Aigbokhan, B. (2005). Fiscal federalism and education, industrial and social development of Nigeria. In Onah F. C. (2005), Fiscal Federalism in Nigeria. Nsukka, Nigeria: Ap Express Publication Ltd.

Central Bank of Nigeria (CBN) (1991). Central Bank Nigeria Economics and Financial Review. Abuja: CBN Publication. December.

CBN (2007). Central Bank Nigeria Economics and Financial Review. Abuja: CBN Publications. December.

Federal Inland Revenue Service (FIRS) (2008). Value Added Tax and Revenue Generation in Nigeria. Abuja: FIRS Publication.

Federal Ministry of Finance (1998). Budget Analysis. Abuja: Federal Ministry of Finance.

Ifesinachi, K. (2005). Federalism in Nigeria today. In Onah F. C. (2005). Fiscal Federalism in Nigeria. Nsukka, Nigeria: AP Express Publications Ltd.

Nigerian National Petroleum Corporation (NNPC) (2009). Partnerships and Challenges. Strategies of Oil Companies in the Face of Globalization: Nigeria Experience. Abuja: NNPC Publication.

Nwankwo, G. (1986). The Nigeria Financial System. Enugu: Fourth Dimension Publishers.

Nzenwa, S. O. (2000) Micro-Credit and Development, Poverty Alleviation in Nigeria. Lagos: Centre for Development and Civic Education

Obasanjo Reforms (2005). Public Service Reform and National Transformation. Abuja: Federal Ministry of Information and Communication, Production and Documentation.

Olukoshi, A. O., Olaniyan, R. O. \& Aribisala, F. (eds.) (1994). Structural Adjustment In West Africa. Ikeja: Pumark Publication Nigeria Ltd.

Omoriyi, I. E. O. (2001). The Dynamics of Community Development: The Nigerian Approach. Benin City: New Era Publication

Onah, F. C. (ed.) (2005). Fiscal Federalism In Nigeria. Nsukka: Great Ap Express Publishers Ltd.

Onyiuke, N. O. (2007). Capital Market Funding for Nigeria University Education System: Challenges and Benefits. Lagos: Nigeria Stock Exchange Publications.

Peter, S. (2005). Introduction to Economic Analysis. Kaduna: Joyce Publishing Coy.

Salawu, R. O. (2005). Essentials of Public Finance. Ile-Ife: Obafemi Awolowo University Press Ltd.

Swammy, R. M. K. (1985). Journal of Institute of Management and Technology. Enugu: IMT Publication. 
The Nations (2005) NSE Capitalization hits $\$ 7$ trillion. June $3^{\text {rd }}$, pp. 42-43

Uzoaga, W. O. (1984). Money and Banking in Nigeria. Enugu: Fourth Dimension Publishers. 